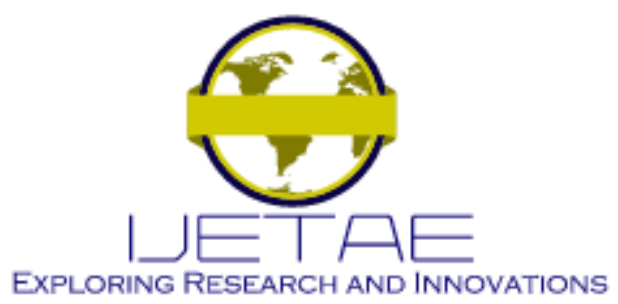

International Journal of Emerging Technology and Advanced Engineering

Website: www.ijetae.com (E-ISSN 2250-2459, Scopus Indexed, ISO 9001:2008 Certified Journal, Volume 11, Issue 11, November 2021)

Manuscript Received: 02 october 2021, Received in Revised form: 05 November 2021, Accepted: 10 November 2021

DOI: $10.46338 /$ ijetae1121_23

\title{
Application of Wireless Sensor Networks to Prevent the Spread of Forest Fires
}

\author{
Le Quang Bon ${ }^{1}$ \\ University of Fire Prevention and Fighting, Vietnam.
}

\begin{abstract}
The objective of this article is to identify current trends and prospects for the use of technical facilities and installations to prevent the spread of wildfires by analyzing the literature. The analysis of the literature has allowed an analysis of different ground-based wildfire detection and monitoring systems: optical sensors and digital camera systems, and wireless sensor network systems. The author concludes that the wireless sensor network can be seen as a partial solution when used in combination with other technologies.
\end{abstract}

Keywords - observation towers, optical systems, optical sensors, digital cameras, wireless sensor network.

\section{INTRODUCTION}

Climate and land-use changes affect forest conditions and functioning. Over the past decades, global temperatures have increased by $0.8^{\circ} \mathrm{C}$ and the climate system is now on track to increase the global average temperature to $+4^{\circ} \mathrm{C}$, although the Paris Agreement 2015 defines a safe maximum temperature increase to $+2{ }^{\circ} \mathrm{C}$ [1]. According to forecasts, negative changes in weather conditions should be expected on the territory of Russia, given the fire danger: increase in air temperature, shift of seasons, increase in the duration of vegetation and fire periods, frequency and intensity of heatwaves and natural hydrometeorological phenomena, and changes in water resources of local drains [2].

Wildfires have reached a large scale worldwide and not only cause great material damage but also lead to the release of $\mathrm{CO} 2$ and chemically active emissions into the atmosphere, negative changes in global carbon balances, the energy balance of the Earth's surface, the water cycle, etc. [3]. In areas of large wildfires, fire mercilessly destroys property and poses a threat to human lives.
The impact of wildfires on ecosystems is complex. Wildfires are not only a disaster for the population but also an important factor in local, regional, and even global environmental dynamics, which is manifested, for example, in fire-induced emissions of greenhouse gases and aerosols into the atmosphere or soil contamination with heavy metals. Wildfires destroy fauna and flora, cause soil erosion, change the regimes of rivers, and cause significant economic losses and negative environmental impacts. The effects of climate change on species and their habitats vary greatly depending on the species, their interactions with other species, and the locations of their habitats. Fire can be a major driver of change in plant communities in the context of climate change. Due to a warming climate and increased recreational pressure on forests, the number and extent are predicted to increase further [4].

Failure to detect wildfires in time leads to serious consequences in the disruption of the natural balance of ecosystems. In this regard, monitoring of potentially hazardous areas facilitates the task of localizing and extinguishing fires at an early stage.

The relevance of the presented work is due to the increasing role of forests as an important element of natural ecosystems, as well as the relentless development of remote sensing technologies. Due to the aggravation of regional and global environmental problems, the need for technological support to prevent the spread of wildfires has arisen.

Research hypothesis: Modern technical facilities and installations to prevent the spread of wildfires should be based on wireless sensor network (WSN) technologies.

\section{METHODS}

The main method of research was the analysis of scientific literature on the research problem. 


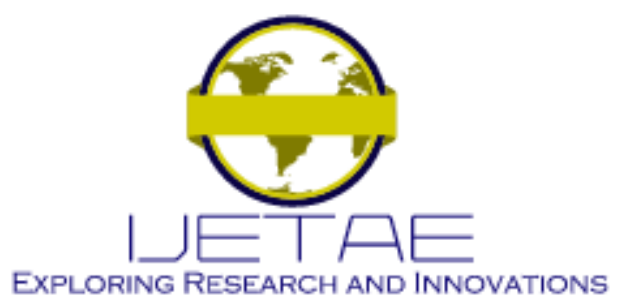

International Journal of Emerging Technology and Advanced Engineering

Website: www.ijetae.com (E-ISSN 2250-2459, Scopus Indexed, ISO 9001:2008 Certified Journal, Volume 11, Issue 11, November 2021)

The scientific sources on the research problem were searched by means of the keywords "wildfire prevention facilities and installations" and "wildfire monitoring facilities and installations" to obtain a reference to the relevant article. The source base was adjusted by the time of publication from 2000 to the present, as well as limited by the requirement of free access to the necessary materials.

The search results revealed more than 3,100 scientific articles and monographs. However, only 19 sources, as the most informative and relevant to the research goal, were analyzed due to the limited size of the article to be published.

\section{RESUltS}

The analysis of literature sources has shown that the main technical means and facilities for ground-based wildfire prevention are the following wildfire detection and monitoring systems:

- observation towers;

- optical systems;

- WSN.

The first method is observation towers, but this method, according to the researchers [5], is inaccurate and ineffective. Although, there is a study [6] according to which a trained observer from the tower is more reliable and faster than optical systems, and one cannot rely on optical cameras alone. However, their implementation could improve the efficiency of the observer.

Other available methods for detecting wildfires are surveillance cameras (optical sensor systems and digital cameras) and a WSN. Let us consider them in more detail.

\section{A. Optical sensor and digital camera systems (OS and DC systems)}

The development of camera technology, image processing, industrial computers, and sensors has led to the automation of early warning systems. Many types of detection are used in ground-based systems [7]:

- spectral detection systems for smoke and fire trail detection during day and night;

- fire detection systems by means of thermal imaging cameras;

- spectral smoke detection systems by means of infra-red spectrometry;

- laser detection systems (LIDAR) based on the principle of laser beam reflection from smoke particles.
The various OS and DC systems use different algorithms but are based on the same concept (smoke and fire trail detection), followed by monitoring of the fire situation and reporting of the emergency situation to the fire services at the fire place. The OS and DC systems are integrated with GIS systems to specify the location of the fire.

The application of OS and DC of a particular type is influenced by both the operating conditions and the amount of funding for firefighting activities.

In Table 1 the most common and promising OS and DC systems are presented.

TABLE I

OS AND DC SYSTEM

\begin{tabular}{|c|c|c|c|}
\hline No. & $\begin{array}{l}\text { OS and CC } \\
\text { system }\end{array}$ & Country & Characteristics \\
\hline 1 & AlarmEYE & Thailand & $\begin{array}{l}\text { early detection system; } \\
\text { includes video cameras and } \\
\text { infra-red cameras; the } \\
\text { working principle is to } \\
\text { distinguish between heat and } \\
\text { fire trace using an infra-red } \\
\text { filter [8] }\end{array}$ \\
\hline 2 & $\begin{array}{l}\text { EYEfi } \\
\text { SPARC }\end{array}$ & Australia & $\begin{array}{l}\text { includes daytime and } \\
\text { nighttime video cameras; } \\
\text { lightning detection sensors; } \\
\text { ultra-high resolution cameras } \\
\text { can be added. The system } \\
\text { does not capture a smoke trail } \\
\text { but provides an additional } \\
\text { source of information after a } \\
\text { smoke trail has been detected } \\
\text { to determine the location of } \\
\text { the fire }[9,10]\end{array}$ \\
\hline 3 & $\begin{array}{ll}\text { Forest } & \text { Fire } \\
\text { Finder } & \end{array}$ & Portugal & $\begin{array}{l}\text { the system's operating } \\
\text { principle is not to detect } \\
\text { smoke and fire trails but to } \\
\text { analyse the atmospheric air } \\
\text { composition. This tracks the } \\
\text { absorption of sunlight by the } \\
\text { atmospheric air, which } \\
\text { depends on changes in the } \\
\text { atmospheric air composition. } \\
\text { Based on the change in } \\
\text { atmospheric air composition, } \\
\text { the system recognizes the } \\
\text { type of smoke particles } \\
\text { depending on their source of } \\
\text { origin (organic/industrial). } \\
\text { The radius of action of the } \\
\text { system is } 15 \mathrm{~km}[11]\end{array}$ \\
\hline
\end{tabular}




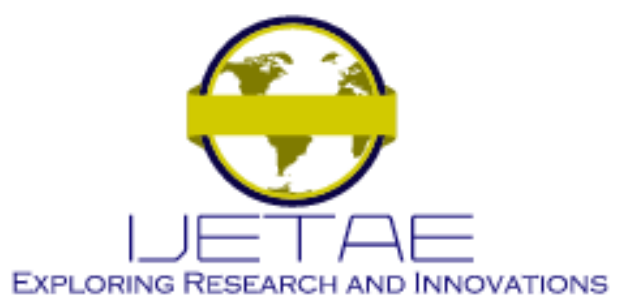

International Journal of Emerging Technology and Advanced Engineering

Website: www.ijetae.com (E-ISSN 2250-2459, Scopus Indexed, ISO 9001:2008 Certified Journal, Volume 11, Issue 11, November 2021)

\begin{tabular}{|c|c|c|c|}
\hline 5 & ForestWatch & RSA & $\begin{array}{l}\text { an optical system for semi- } \\
\text { automated detection of smoke } \\
\text { trails during daytime and fire } \\
\text { trails at night; includes sensor } \\
\text { cameras that are placed on } \\
\text { towers and scan the } \\
\text { surrounding area up to } 20 \mathrm{~km} \\
\text { in radius. The system } \\
\text { includes [12]: sensor cameras } \\
\text { with a variable full-length } \\
\text { angle and } 24 \mathrm{x} \text { magnification, } \\
\text { communication system, } \\
\text { image-sampling device, and } \\
\text { software for situational } \\
\text { awareness. Most common } \\
\text { system: } 83 \text { towers in South } \\
\text { Africa, } 22 \text { towers in the USA, } \\
20 \text { towers in Chile, and } 4 \\
\text { each in Canada and Slovakia } \\
{[13]}\end{array}$ \\
\hline 6 & FireWatch & Germany & $\begin{array}{l}\text { automatic smoke trace } \\
\text { detection system within a } \\
\text { radius of } 10 \text { to } 40 \mathrm{~km} \text {. It } \\
\text { includes optical sensors that } \\
\text { make a full rotation in steps } \\
\left(10^{\circ}\right) \text { of } 4-6 \text { min during the } \\
\text { day and } 8-12 \text { min during the } \\
\text { night; and a wireless } \\
\text { communication system for } \\
\text { data transfer. Used mainly in } \\
\text { Germany [14] }\end{array}$ \\
\hline 7 & FireHawk & RSA & $\begin{array}{l}\text { the system allows identifying } \\
\text { the exact location of the fire; } \\
\text { the system includes installed } \\
\text { cameras, wireless } \\
\text { communication channels; } \\
\text { GIS systems and original } \\
\text { software to determine the } \\
\text { location and shortest routes to } \\
\text { the location of the fire [15] }\end{array}$ \\
\hline
\end{tabular}

The results of a study [16] on optical wildfire detection systems have led to the following conclusions. Optical systems need better and smarter algorithms and methods concerning the number of false alarms caused by various dynamic phenomena such as reflections, wind wavering trees, human activity, and cloud shadows. Landscape images are very difficult to process due to the variety of nature and dynamic events that can cause different illumination depending on distance, weather, object masking, time of day, etc.
Optical systems can cover a large area (up to $80 \mathrm{~km}$ in radius) with the observation of forests. However, the main problem with optical systems is that they can only detect fires within the line of sight. Surveillance will be difficult in hilly and mountainous terrain and the presence of tall trees. Changing weather conditions and nights also make optical systems difficult to use. A final challenge is the cost of optical systems: the cost of an optical tower reaches USD 30,000 and the need for a suitable communications infrastructure in a remote location leads to additional financial costs.

\section{B. WSN}

The solution to the problem of optical cameras, associated with possible obstacles within line-of-sight, is solved by a different kind of sensor. The so-called WSN is a new technology that can also be used for the detection of forest fires. WSN typically consist of miniature computing devices equipped with sensors and transceivers operating in a specific shortwave radio range. Sensors can record the following physical environmental parameters: atmospheric pressure, ambient temperature, thermal radiation, humidity, etc. WSN are usually installed randomly over a large area in remote or inaccessible locations.

Advances in sensor network technology have enabled the use of this technology for the early detection of wildfires. In the work [13], the South Korean FFSS system is presented as an example of a wireless sensor network system using a fire identification algorithm based on spectral analysis of smoke. The work [14] considers the FireWxNet wireless sensor network system - a multi-level portable wireless system for monitoring weather conditions in forest fires. As an example of using the system, it describes its full deployment using three sensor networks and two web cameras; an analysis of the system performance is presented. In the work [15], as an example of the current state of algorithms, protocols, and hardware for wireless sensor networks, a description of a special purpose-oriented EU research project capable of extracting multimedia content (video and audio streams, still images, scalar sensor data) from the environment is presented. Consider the most popular and promising systems (Table 2). 


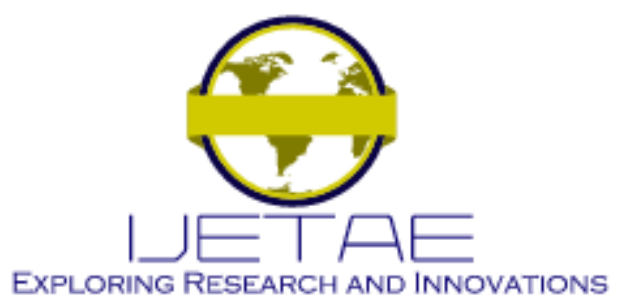

International Journal of Emerging Technology and Advanced Engineering

Website: www.ijetae.com (E-ISSN 2250-2459, Scopus Indexed, ISO 9001:2008 Certified Journal, Volume 11, Issue 11, November 2021)

TABLE II

WSN SYSTEMS

\begin{tabular}{|c|c|c|c|}
\hline No. & $\begin{array}{c}\text { WSN } \\
\text { system }\end{array}$ & Country & Characteristics \\
\hline 1 & FFSS & $\begin{array}{l}\text { South } \\
\text { Korea }\end{array}$ & $\begin{array}{l}\text { recorded environmental } \\
\text { parameters: lighting, air } \\
\text { temperature, and humidity. } \\
\text { The results of the observations } \\
\text { are recorded daily in a } \\
\text { database and compared with } \\
\text { the norm to assess the } \\
\text { potential fire risk [17]. }\end{array}$ \\
\hline 2 & $\begin{array}{l}\text { FireWx } \\
\text { Net }\end{array}$ & Canada & $\begin{array}{l}\text { It is characterised by a multi- } \\
\text { layered structure: a network of } \\
\text { wireless sensors is used to } \\
\text { record environmental } \\
\text { parameters, while webcams } \\
\text { and GPS are used to obtain } \\
\text { images of the location of the } \\
\text { fire. The algorithm is based on } \\
\text { the Fire Weather Index (FWI), } \\
\text { through which the probability } \\
\text { of fire and its rate of spread } \\
\text { are determined [18]. }\end{array}$ \\
\hline 3 & $\begin{array}{l}\text { FIRESE } \\
\text { NSE }\end{array}$ & EU & $\begin{array}{l}\text { A unified system for } \\
\text { surveillance of inaccessible } \\
\text { areas and early warning of } \\
\text { fires. The system includes } \\
\text { infrared cameras, optical and } \\
\text { temperature sensors. The } \\
\text { system records and processes } \\
\text { observation results and } \\
\text { transmits them to local } \\
\text { authorities [12]. }\end{array}$ \\
\hline
\end{tabular}

A study [19] has shown that a WSN is a suitable network for signalling a rapid wildfire outbreak in a target area. These systems are currently receiving a lot of attention because of their usefulness in wildfire detection, environmental sensing, and data computation.
WSN can raise an alarm, switch off during a power surge, transmit messages when a fire is detected early. The wireless unit monitors the presence of carbon monoxide (IV), carbon monoxide (II), nitrogen monoxide (II), atmospheric pressure, relative humidity, and temperature.

WSN technology, which is usually deployed in a large number of sensors, allows monitoring of the environment by transmitting the observations directly for processing. Thus, there is no need to build towers or install complex communication links such as microwave and satellite links.

Thus, this study compared different technical facilities and installations for detecting and preventing the spread of wildfires.

The results of the study show that the method of detecting and preventing the spread of wildfires using observation towers is inaccurate and ineffective. The use of optical systems is also ineffective, as cameras are installed manually and there are image problems at night and lack of line of sight in some cases. Thus, WSN can be a partial solution to the problem of early detection and prevention of wildfire spreading, if this technology is integrated with digital cameras, weather databases, etc.

The results of the study confirmed the hypothesis that modern technical means and facilities for the prevention of wildfire spreading should be based on WSN technologies.

\section{REFERENCES}

[1] Eliseev, I. B., Sai, V. V., Menshov, S. V., Voitenok, O. V., Shkitronov, M. E. 2020. Organization of fire fighting and carrying out crash-rescue operations in the buildings and structures under major renovation. EurAsian Journal of Biosciences, 14, 6133-6136.

[2] Utebekova, A., Maisupova, B., Mambetov, B., Dosmanbetov, D., Kelgenbayev, N., Abzhanov, T. 2021. Analysis of tree-ring chronologies in coniferous forests of Southeastern Kazakhstan. OnLine Journal of Biological Sciences, 21(1), 41-47. DOI: 10.3844/ojbsci.2021.41.47

[3] Ryskaliyev, M. Zh., Zharylgapov, S. M., Saktaganova, N. A., Sarabekova, U. Zh., Abdikerova, U. B. 2020. The influence of annealing temperature on variation of physicomechanical properties of wall ceramic tiles based on loess loam modified by oil sludge. ARPN Journal of Engineering and Applied Sciences, 15(2), 25972602.

[4] Bowman, D. M. J. S., Johnston, F. H. 2005. Wildfire smoke, fire management, and human health. EcoHealth, 2(1), 76-80. DOI: 10.1007/s10393-004-0149-8

[5] Fernandez-Berni, J., Carmona-Galan, R., Carranza-Gonzalez, L. 2008. A vision-based monitoring system for very early automatic detection of forest fires. WIT Transactions on Ecology and the Environment, 119, 161-170. DOI: 10.2495/FIVA080171 


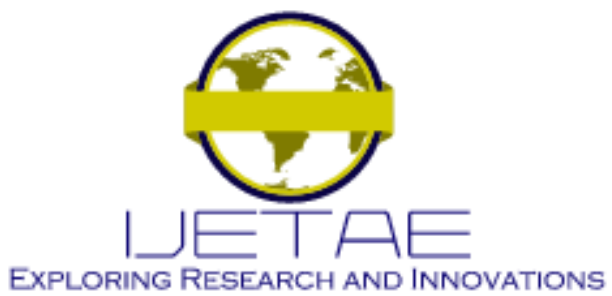

International Journal of Emerging Technology and Advanced Engineering Website: www.ijetae.com (E-ISSN 2250-2459, Scopus Indexed, ISO 9001:2008 Certified Journal, Volume 11, Issue 11, November 2021)

[6] Pradhan, B., Dini Hairi Bin Suliman, M., Arshad Bin Awang, M. 2007. Forest fire susceptibility and risk mapping using remote sensing and geographical information systems (GIS). Disaster Prevention and Management, 16, 3, 344-352. DOI: $10.1108 / 09653560710758297$

[7] Barmpoutis, P., Papaioannou, P., Dimitropoulos, K., Grammalidis, N. 2020. A review on early forest fire detection systems using optical remote sensing. Sensors, 20, 6442. DOI: $10.3390 / \mathrm{s} 20226442$

[8] Memane, S. E., Kulkarni, V. S. 2015. A review on flame and smoke detection techniques in video's. International Journal of Advanced Research in Electrical, Electronics and Instrumentation Engineering, 4, 885-889.

[9] Bouabdellah, K., Noureddine, H., Larbi, S. 2013. Using wireless sensor networks for reliable forest fires detection. Procedia Computer Science, 19, 794-801. DOI: 10.1016/j.procs.2013.06.104

[10] Aslan, Y. E., Korpeoglu, I., Ulusoy, O. 2012. A framework for use of wireless sensor networks in forest fire detection and monitoring. Computers, Environment and Urban Systems, 36, 614-625. DOI: 10.1016/j.compenvurbsys.2012.03.002

[11] De Almeida, R. V., Vieira, P. 2017. Forest fire finder - DOAS application to long-range forest fire detection. Atmospheric Measurement Techniques, 10, 2299-2311. DOI: 10.5194/amt-102299-2017

[12] Akyildiz, I., Melodia, T., Chowdhury, K. 2007. A survey on wireless multimedia sensor networks. Computer Networks, 51(4), 921-960. DOI: 10.1016/j.comnet.2006.10.002
[13] Lalkovič, M., Pajtíková, J. 2010. Forestwatch® wildfire smoke detection system: lessons learned from its two-year operational trial. WIT Transactions on Ecology and the Environment, 137, 131-141. DOI: $10.2495 /$ FIVA100121

[14] Günay, O., Tasdemir, K., Töreyin, B. U., Çetin, A. E. 2010. Fire detection in video using LMS based active learning. Fire Technology, 46, 551-577. DOI: 10.1007/s10694-009-0106-8

[15] Memane, S. E., Kulkarni, V. S. 2015. A review on flame and smoke detection techniques in videos. International Journal of Advanced Research in Electrical, Electronics and Instrumentation Engineering, 4, 885-889.

[16] Yuan, C., Zhang, Y., Liu, Z. 2015. A survey on technologies for automatic forest firemonitoring, detection, and fighting using unmanned aerial vehicles and remote sensing techniques. Canadian Journal of Forest Research, 45, 783-792. DOI: 10.1139/cjfr-20140347

[17] Li, X., Song, W., Lian, L., Wei, X. 2015. Forest fire smoke detection using back-propagation neural network based on MODIS data. Remote Sensing, 7, 4473-4498. DOI: 10.3390/rs70404473

[18] Hartung, C., Han, R., Seielstad, C., Holbrook, S. 2006. FireWxNet: A Multi-Tiered Portable Wireless System for Monitoring Weather Conditions in Wildland Fire Environments. Proceedings of the 4th International Conference on Mobile Systems, Applications, and Services (MobiSys 2006), p. 28-41.

[19] Muhammad, K., Ahmad, J., Baik, S. W. 2018. Early fire detection using convolutional neural networks during surveillance for effective disaster management. Neurocomputing, 288, 30-42. DOI: 10.1016/j.neucom.2017.04.083 